\title{
Antioxidant, genotoxic, antigenotoxic, and antineoplastic activities of apitoxin produced by Apis mellifera in Northeast, Brazil
}

\section{Geysa Almeida Viana ${ }^{1}\left(\right.$ Carlos Iberê Alves Freitas ${ }^{1}$ () José Gustavo Lima de Almeida ${ }^{1}$ ([) Gerard Vicente Dantas de Medeiros ${ }^{1}\left([)\right.$ Tiago da Silva Teófilo ${ }^{1 *}\left({ }^{*}\right.$ Victor Hugo Vieira Rodrigues ${ }^{1}([)$ Wesley Adson Costa Coelho ${ }^{1}$ ] Jael Soares Batista ${ }^{1} \odot$}

${ }^{1}$ Departamento de Ciências Animais, Centro de Ciências Agrárias, Universidade Federal Rural do Semi-Árido (UFERSA), 59625-900, Mossoró, RN, Brasil. E-mail: tiagosteofilo@gmail.com. "Corresponding author.

ABSTRACT: The objective was to evaluate the in vitro antioxidant, genotoxic, antigenotoxic, and antineoplastic activities of apitoxin produced by the bee Apis mellifera. The antioxidant activity of the apitoxin solution was evaluated using the DPPH (2,2-diphenyl-1-picrilhydrazyl) method. Genotoxic potential of apitoxin was analyzed by comparing the mean DNA damage indices (idDNA) of L929 strain fibroblasts exposed to hydrogen peroxide $\left(\mathrm{H}_{2} \mathrm{O}_{2}\right.$ genotoxic substance), distilled water, or apitoxin. The antigenotoxic effect of apitoxin was analyzed by assessing the percentage decrease in $\mathrm{H}_{2} \mathrm{O}_{2}$-induced genotoxicity in L929 fibroblasts co-treated with three concentrations of the aqueous apitoxin solution and subjected to comet assay. In vitro antineoplastic activity in human tumor cell lines of prostate adenocarcinoma (PC3), hepatocellular carcinoma (HEPGE2), melanoma (MAD-MB435), and astrocytoma (SNB19), were verified by MTT [3- (4) bromide colorimetric method, 5-dimethylthiazol-2-yl) -2,5-diphenyltetrazolium]. Apitoxin had no genotoxic effect on L929 cells at concentrations of 30, 10, and $5 \mu \mathrm{g} /$ $m L$ after 24 hours of exposure. This effect was only evident at $50 \mu \mathrm{g} / \mathrm{mL}$. Apitoxin promoted a significant reduction in DNA damage index (idDNA) at all concentrations tested. At $30 \mu \mathrm{g} / \mathrm{mL}$, apitoxin attenuated the genotoxic effects induced by $\mathrm{H}_{2} \mathrm{O}_{2}$. Apitoxin also demonstrated in vitro antineoplastic potential, since the cytotoxic effect was observed at concentrations of $50 \mu \mathrm{g} / \mathrm{mL}$ and $25 \mu \mathrm{g} / \mathrm{mL}$, with significant reduction in viability percentage of PC3 tumor cell lines, HEPGE2, MAD-MB435, and SNB19. The high antioxidant activity associated with the absence of genotoxic effect and the genoprotective and antineoplastic effect demonstrated by apitoxin here provide indications of apitoxin's therapeutic potential. Key words: Bee venom, Genoprotection, In vitro antitumor activity.

Atividades antioxidantes, genotóxicas, antigenotóxicas e antineoplásicas da apitoxina produzida por Apis mellifera no Nordeste do Brasil

RESUMO: $O$ objetivo deste estudo foi avaliar as atividades antioxidantes, genotóxicas, antigenotóxicas e antineoplásicas in vitro da apitoxina produzida pela abelha Apis mellifera. A atividade antioxidante da solução da apitoxina foi avaliada pelo método DPPH (2,2-difenil1-picrilhidrazil). O potencial genotóxico da apitoxina foi analisado através dos índices médios de dano ao DNA (idDNA) dos fibroblastos da linhagem $\mathrm{L} 929$ expostos à peróxido de hidrogênio $\left(\mathrm{H}_{2} \mathrm{O}_{2}\right.$ - substância genotóxica), água destilada ou apitoxina. O efeito antigenotóxico da apitoxina foi analisado através da avaliação da diminuição percentual na genotoxicidade induzida por $\mathrm{H}_{2} \mathrm{O}_{2}$ nos fibroblastos $\mathrm{L} 929$ co-tratados com três concentrações da solução aquosa de apitoxina e submetidos ao ensaio cometa. A atividade antineoplásica in vitro em linhagens celulares tumorais humanas de adenocarcinoma da próstata (PC3), carcinoma hepatocelular (HEPGE2), melanoma (MAD-MB435) e astrocitoma (SNB19), foram verificadas pelo método colorimétrico do brometo de MTT [3- (4), 5-dimetiltiazol-2-il) -2,5-difeniltetrazólio]. A apitoxina não teve efeito genotóxico nas células L929 nas concentrações de 30, 10 e $5 \mu \mathrm{g} / \mathrm{mL}$ após 24 horas de exposição. Este efeito foi apenas evidente a 50 $\mu \mathrm{g} / \mathrm{mL}$. A apitoxina promoveu uma redução significativa no índice de danos ao DNA (idDNA) em todas as concentrações testadas. A $30 \mu \mathrm{g} / \mathrm{mL}$, a apitoxina atenuou os efeitos genotóxicos induzidos por $\mathrm{H}_{2} \mathrm{O}_{2}$ A apitoxina também demonstrou potencial antineoplásico in vitro, uma vez que o efeito citotóxico foi observado em concentrações de $50 \mu \mathrm{g} / \mathrm{mL}$ e $25 \mu \mathrm{g} / \mathrm{mL}$, com redução significativa na porcentagem de viabilidade das linhagens celulares de PC3, HEPGE2, MAD-MB435 e SNB19. A alta atividade antioxidante associada à ausência de efeito genotóxico e o efeito genoprotetor e antineoplásico demonstrado pela apitoxina aqui fornecem indicações do potencial terapêutico da apitoxina.

Palavras-chave: Veneno de abelha, Genoproteção, Atividade antitumoral in vitro.

\section{INTRODUCTION}

Among the products of apiculture origin, apitoxin has stood out for presenting important therapeutic properties and aroused interest from the pharmaceutical industry for the extraction of new bioactive principles to be used in medicine manufacturing (CHERNIACK, 2010; RATCLIFFE et al., 2011). Apitoxin is the poison produced by Apis mellifera through two glands located inside the worker 
bee's abdomen. It protects the colony against a wide variety of predators ranging from other arthropods to vertebrates (SCIANI et al., 2010; ORŠOLIĆ, 2012; RATCLIFFE et al., 2011).

The composition of apitoxin consists of $88 \%$ water, and the remaining $12 \%$ contains several components (LEANDRO et al., 2015). This composition may vary depending on age, seasonality, and geographical regions. Among the components that stand out the most are melithin and phospholipase A2, which together represent about $75 \%$ of the dry weight (FERREIRA-JUNIOR et al., 2010; SCIANI et al., 2010).

Studies showed that bee venom has several therapeutic activities, including hemolytic, analgesic, anti-inflammatory, antibacterial, antifungal (ZHOU et al., 2010; ORŠOLIĆ, 2011; YANG et al., 2011), antinociceptive (KIM et al., 2003), hepatoprotective (PARK et al., 2010) antiviral, and antitumor effects (ZHOU et al., 2010; ORŠOLIĆ, 2012; RATCLIFFE et al., 2011; YANG et al., 2011). Apitoxin has also shown significant therapeutic potential in the treatment of neurodegenerative diseases like amyotrophic lateral sclerosis (ALS) (YANG et al., 2011; LEE et al., 2012), Alzheimer's (SUN et al., 2004) and Parkinson's disease (DOO et al., 2010; KIM et al., 2011a; KIM et al., 2011b; CHUNG et al., 2012, YOON et al., 2013). Its use in the cosmetics industry has also been widely explored, mainly as an aid in delaying aging (HAN et al., 2012).

Greater knowledge of the biological activity of apitoxin extracted from beehives in Northeast Brazil may contribute to confirm its therapeutic value and improve its application for various purposes. Thus, the study aimed to evaluate the potential of apitoxin produced by bee Apis mellifera, specifically focusing on its antioxidant, genotoxic, antigenotoxic, and antineoplastic activity in vitro.

\section{MATERIALS AND METHODS}

\section{Obtaining Apitoxin Samples}

Apitoxin samples from Apis mellifera bees were collected in Maxaranguape city, State of Rio Grande do Norte, beginning in July 2017. Apitoxin was collected by electrical stimulation according to the methodology adapted from GRAMACHO et al., (1992). Glass collecting plates were placed above the hives and connected to a device that promotes electrical impulses of $45 \mathrm{~V}$, with 1-second pulse interval and $14 \mathrm{~mA}$ ampere.

After drying in a forced air oven at $40{ }^{\circ} \mathrm{C}$ for 48 hours, the poison was scraped from the glass and weighed on a precision analytical balance. $1 \mathrm{~g}$ of the venom was collected and a $50 \mathrm{mg} / \mathrm{mL}$ solution was prepared using distilled water as a diluent. The finished solution was stored in an amber glass container, wrapped in laminated paper, and frozen $\left(-20^{\circ} \mathrm{C}\right)$ until use.

The collection techniques used followed the determinations of Normative Instruction No. 3 of January 19, 2001 of the Ministry of Agriculture, aiming at a sample with standard quality.

\section{Evaluation of antioxidant activity}

The in vitro photocolorimetric method of the free radical DPPH (2,2-diphenyl-1-picrylhydrazine) described by MENSOR et al. (2001) was used to evaluate the antioxidant activity. $1 \mathrm{mg} / \mathrm{mL}$ apitoxin solution was gradually diluted in methanol, resulting in different concentrations $(1,0.8,0.6,0.4,0.2$, and $0.1 \mathrm{mg} / \mathrm{mL}$ ). $1 \mathrm{ml}$ of each concentration was placed in test tubes together with $1.5 \mathrm{~mL}$ of a $60 \mu \mathrm{mol} / \mathrm{L} \mathrm{DPPH}$ methanolic solution. After 15 minutes the absorbance of the spectrophotometer was measured at a wavelength of $517 \mathrm{~nm}$ with only methanol as blank.

Ascorbic acid was used in this experiment as a positive control at the same concentrations as the test samples. The inhibition percentage for each concentration of apitoxin solution was obtained from the ratio of its absorption to the absorbance of a solution containing $1 \mathrm{~mL}$ methanol and $1.5 \mathrm{~mL}$ DPPH solution.

The ability to inhibit the DPPH radical (\% antioxidant activity) was calculated using the equation:

Antioxidant activity $(\%)=\frac{\text { Control Absorbance-Sample Absorbance }}{\text { Control Absorbance }} * 100$

The standard DPPH curve was constructed by plotting the mean value of the absorbance obtained by the solution concentrations. After obtaining the free radical percentage inhibition values, they were analyzed in Oringin 7.0 Software to obtain a graph showing values by which the $50 \%$ inhibitory concentration of the DPPH radical (IC50) would be calculated, which is the sample concentration required to consume $50 \%$ of the DPPH.

\section{Evaluation of the genotoxic and antigenotoxic potential of apitoxin}

The genotoxic effect of apitoxin solution on L929 fibroblasts $\left(0.7 \times 10^{5}\right.$ cells $\left./ \mathrm{mL}\right)$ cultured in DMEM (Dulbecco modification of Minimum Essential Media; GIBCO $^{\circledR}$ ) supplemented with $10 \%$ fetal bovine serum and $1 \%$ antibiotics was evaluated and subjected to comet assay. The cells were exposed to hydrogen peroxide $\left(\mathrm{H}_{2} \mathrm{O}_{2} ; 150 \mu \mathrm{M}\right.$ for $\left.2 \mathrm{~h}\right)$ to 
induce genotoxicity (positive control) or sterile distilled water (negative control). Cell cultures were also co-treated with increasing concentrations of apitoxin $(50,30,10$, and $5 \mu \mathrm{g} / \mathrm{mL})$ and $\mathrm{H}_{2} \mathrm{O}_{2}(150$ $\mu \mathrm{M})$ solution samples for $2 \mathrm{~h}$ at $37^{\circ} \mathrm{C}$ in a $5 \% \mathrm{CO}_{2}$ atmosphere (test group).

The cells were homogenized in $0.8 \%$ agarose and spread on prepared slides, which were immersed in lysis solution for $1 \mathrm{~h}$ before neutralizing. Subsequently, the slides were kept in electrophoresis buffer at $4{ }^{\circ} \mathrm{C}$ for 20 minutes, followed by running for 20 minutes at $1.6 \mathrm{~V} / \mathrm{cm}$. The slides were stained in an ethidium bromide solution $(20 \mu \mathrm{g} / \mathrm{mL})$ and analyzed using a fluorescence microscope.

The degree of DNA damage was visually identified by analyzing the tail formed by the DNA fragments, and the tail size was proportional to the extent of damage caused (MEZZALIRA et al., 2014). One hundred comets per slide were analyzed and classified by visual analysis into five categories $(0,1$, 2,3 , and 4), which represent the percentage of DNA in the comet's tail, indicating the degree of injury sustained by the cell (LOVELL et al., 1999).

The damage index (DI) was obtained using the following formula: DI $=\sum^{4} n_{i} \times i$, where $n_{i}$ is the number of cells with damage level ${ }^{i}(0,1,2,3$, or 4$)$.

The protective effect of test samples on $\mathrm{H}_{2} \mathrm{O}_{2}$-induced genotoxicity (50 $\mu \mathrm{M}$ per $2 \mathrm{~h}$ exposure) was calculated according to WATERS et al. (1990) according to the formula: \% Reduction $=(\mathrm{AB} / \mathrm{AC})$ $\mathrm{x} 100$, where A corresponds to the DI induced by $\mathrm{H}_{2} \mathrm{O}_{2}, \mathrm{~B}$ corresponds to the $\mathrm{DI}$ induced by antineotoxic treatment $\left(\mathrm{H}_{2} \mathrm{O}_{2}+\right.$ test sample), and $\mathrm{C}$ corresponds to the DI assigned to the negative control (distilled water).

\section{In vitro antineoplastic activity evaluation}

The in vitro antineoplastic potential of apitoxin was evaluated by the cytotoxic effect of apitoxin on four human tumor cell lines: prostate adenocarcinoma (PC3), hepatocellular carcinoma (HEPGE2), melanoma (MAD-MB435), astrocytoma (SNB19), and non-neoplastic healthy fibroblast line (L929), which were used to compare and evaluate the selective effect of apitoxin cytotoxicity between tumor and normal cells. The tumor lines were from the Rio de Janeiro Cell Bank (BCRJ) and supplied by Biotechcell ${ }^{\circledR}$, a company incubated at the Federal University of Ceará (UFC).

Evaluation of cytotoxic activity was performed using the colorimetric MTT [3(4,5-dimethylthiazol-2-yl) -2,5-diphenyltetrazolium bromide] method using the methodology described by MOSMAN in 1983 . The cells were distributed in plates of 96 wells and exposed at different concentrations of the aqueous apitoxin solution: 50, $25,12.5,6.25,3.125,1.5625$, and $0.78125 \mu \mathrm{g} / \mathrm{mL}$. The plates were incubated for $72 \mathrm{~h}$ at $5 \% \mathrm{CO}_{2}$ at $37{ }^{\circ} \mathrm{C}$. Subsequently, $10 \mu \mathrm{L}$ of the MTT reagent at $5 \mathrm{mg} / \mathrm{mL}$ was added to all wells, and the plate was incubated again for 4 hours at $5 \% \mathrm{CO}_{2}$ at $37^{\circ} \mathrm{C}$.

After this period, the absorbance of the resulting solutions was measured using a plate spectrophotometer at a wavelength of $595 \mathrm{~nm}$. The assay was performed in triplicate using three independent experiments. Chemotherapeutic doxorubicin was used at a concentration of $5 \mu \mathrm{g} / \mathrm{mL}$ as a positive control, and the sample solvent (distilled water) as negative control was used. Results are expressed as percentage of mean \pm standard deviation of cell viability relative to negative control (compared to $100 \%$ viability). Cell viability (percentage of cell survival) was estimated using the following equation:

Viability $(\%)=\left(\frac{\text { sample absorbance }}{\text { negative control absorbance }}\right) * 100$

\section{Cytotoxicity and tumor selectivity index}

From the viability data obtained for each concentration of the evaluated samples, the $50 \%$ cytotoxicity index (IC50) corresponding to the sample concentration capable of inducing $50 \%$ cytotoxicity was determined for each cell line tested. These were compared with the doxorubicin IC50. The tumor selectivity index (STI) was determined by the ratio between the IC50 obtained for non-neoplastic fibroblasts (L929) and the human neoplastic strains prostate adenocarcinoma (PC3), hepatocellular carcinoma (HEPGE2), astrocytoma (SNB19) and melanoma (MAD-MB435), according to HORII et al. (2012).

\section{Statistical analysis}

The mean absorbance data obtained from the test, positive control, and negative control samples were compared using ANOVA analysis of variance followed by Tukey post-test using the Prisma version 5.0 program (GraphPad Software) with a significance level of $\mathrm{P}<0.05$.

\section{RESULTS AND DISCUSSION}

\section{Antioxidant activity}

The graph obtained by the inhibition percentages (\% DPPH consumed) in the different concentrations of apitoxin showed a linear pattern. Higher solution concentrations corresponded to higher DPPH consumption and lower the absorbances. The 
highest percentages of DPPH inhibition were obtained at concentrations of $1 \mathrm{mg} / \mathrm{mL}$ and $0.8 \mathrm{mg} / \mathrm{mL}$, which were respectively $74.92 \%$ and $60.85 \%$ (Figure 1).

The sequestering capacity of the DPPH radical can be represented by the IC50 values (\%), which is an indicative parameter of the inhibitory concentration required to decrease the free radical DPPH (IC50) by 50\% (NASCIMENTO et al., 2015). In general, lower IC50 values (\%) correspond to higher the sequestering capacity of the radical and higher antioxidant activity (CAMPOS et al., 2012). Results showed that the inhibitory capacity of apitoxin solution (IC50) was $0.648 \mathrm{mg} / \mathrm{mL}$. We concluded that apitoxin had good antioxidant activity compared to standard ascorbic acid antioxidant (IC50 $=0.255 \mathrm{mg} / \mathrm{mL}$ ), a reference substance frequently used in antioxidant activity analyzes due to its ability to rapidly reduce DPPH. Similar values $(\mathrm{IC} 50=0.225$ $\mu \mathrm{g} / \mathrm{mL}$ ) were reported by SOBRAL et al. (2016) in samples of the poison produced by Apis mellifera iberiensis from Northeast Portugal.

\section{Genotoxic and antigenotoxic activity}

Exposure to so-called genotoxic agents, which interact with DNA and produce changes in its structure or function, can interfere with essential cell processes like replication and transcription. As a consequence, they lead to cell death and induce cancer-causing mutations (HOEIJMAKERS, 2009). In this context, genetic toxicology is an area that has been dedicated to the identification and study of the mechanisms of action of agents that produce toxic effects to genetic material (AQUINO, 2010).

Therefore, genotoxicity studies help to evaluate the safety and effectiveness of natural products (BAST, 2002). Thus, the search for agents that can reduce the frequency of DNA changes has been promising, and it has important implications for therapeutic practices due to the possibility of reducing the mutation rate and decreasing the incidence of diseases linked to genetic material changes (MARTINI et al., 2012).

Here, we used the comet assay to determine the genotoxic effects of apitoxin compared to the genotoxic substance $\mathrm{H}_{2} \mathrm{O}_{2}$, which promotes oxidative DNA damage. Also, L929 fibroblasts were exposed to $\mathrm{H}_{2} \mathrm{O}_{2}$ and co-treated with three different concentrations of the aqueous apitoxin solution after $24 \mathrm{~h}$ of incubation, to evaluate the antigenotoxic effect of apitoxin.

Results showed that apitoxin had no genotoxic effect on murine fibroblasts (L929) at the 30,10 , and $5 \mu \mathrm{g} / \mathrm{mL}$ concentrations tested. This effect was only shown at $50 \mu \mathrm{g} / \mathrm{mL}$ after $24 \mathrm{~h}$ of exposure. No significant differences were observed in mean DNA damage index (idDNA) values of L929 cells treated with aqueous apitoxin solution (test group) at concentrations of 30,10 , and $5 \mu \mathrm{g} / \mathrm{mL}$ and sterile distilled water (negative control). Meanwhile, apitoxin promoted significant reduction of idDNA

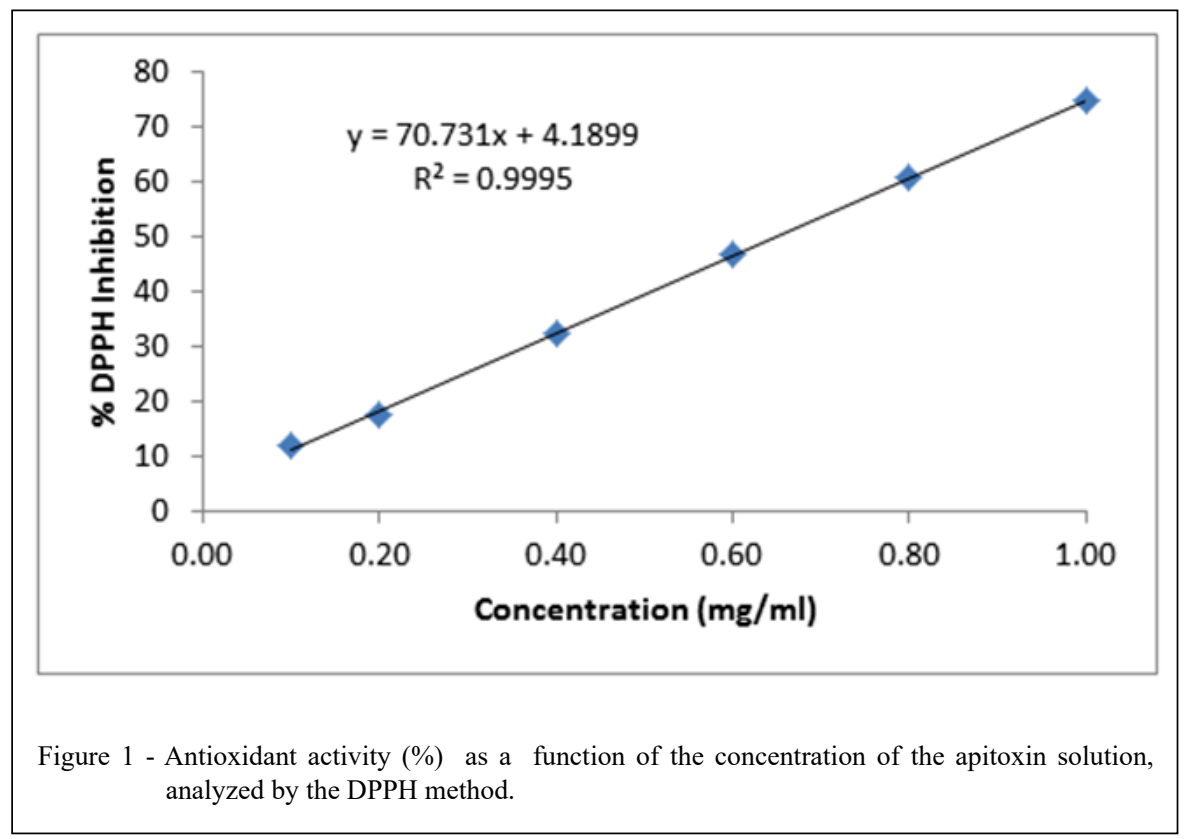

Ciência Rural, v.51, n.4, 2021. 
at the mentioned concentrations compared to the positive control, which included cells treated with the genotoxic substance $\mathrm{H}_{2} \mathrm{O}_{2}$ (Table 1).

In addition, apitoxin at a concentration of $30 \mu \mathrm{g} / \mathrm{mL}$ moderately attenuated the $\mathrm{H}_{2} \mathrm{O}_{2}$-induced genotoxic effects. The percentage reduction in genotoxicity was $51.2 \pm 10.6$ at this concentration, demonstrating a satisfactory protective effect against cellular DNA damage and antigenotoxic potential (Table 2). The percentage reduction in genotoxicity indicated that apitoxin reduces genetic damage caused by free radicals. This effect seems to be mediated by the antioxidant activity of apitoxin, as shown here, where apitoxin had good antioxidant activity (AI50 $=0.648 \mathrm{mg} / \mathrm{mL}$ ). Thus, apitoxin probably interacted with $\mathrm{H}_{2} \mathrm{O}_{2}$, blocking its deleterious effect on DNA, exerting genoprotective activity, and protecting DNA.

The finding that apitoxin may act as an antioxidant is very interesting, since the literature shows that deleterious effects on DNA and other endogenous molecules are common in diseases like cancer, diabetes, arthritis, cardiovascular disease, brain dysfunction, aging, and others (OLIVEIRA et al., 2011).

\section{Antineoplastic activity}

We evaluated the in vitro cytotoxic effect of apitoxin on human tumor cell viability of prostate adenocarcinoma (PC3), hepatocellular carcinoma (HEPGE2), astrocytoma (SNB19), and melanoma (MAD-MB435) to determine the antineoplastic activity of apitoxin.

Apitoxin was reported to be cytotoxic for all neoplastic strains, demonstrating that the ability to decrease viability was concentration dependent. Low percentages of cell viability were observed in all tested neoplastic cell lines at concentrations of 50 $\mu \mathrm{g} / \mathrm{mL}$ and $25 \mu \mathrm{g} / \mathrm{mL}$. When comparing the viability percentages in the different concentrations tested, it was observed that there was a significant reduction in cell viability percentages at concentrations of $50 \mu \mathrm{g} /$
$\mathrm{mL}$ and $25 \mu \mathrm{g} / \mathrm{mL}$ compared to the values obtained in the other concentrations in all tested strains. Also, it was found that apitoxin exerted moderate cytotoxic activity at the $12.5 \mu \mathrm{g} / \mathrm{mL}$ concentration in all strains tested. In this concentration, the viability percentage differed significantly compared to the other concentrations. In all cell lines tested, it was observed that from the concentration of $6.25 \mu \mathrm{g} / \mathrm{mL}$ apitoxin did not present cytotoxic activity. High cell viability values and the absence of significant differences in the percentage viability values between the two cells were observed at the concentrations of $6.25 \mu \mathrm{g} / \mathrm{mL}, 3,125$ $\mu \mathrm{g} / \mathrm{mL}, 1.5625 \mu \mathrm{g} / \mathrm{mL}$ and $0.78125 \mu \mathrm{g} / \mathrm{mL}$ (Table 3).

The MTT assay is a test that analyzes cell viability or proliferation via cell damage as the succinate dehydrogenase enzyme present in living cell mitochondria reduces the MTT salt [3- (4,5-dimethylthiazol-bromide) 2-yl) -2,5-diphenyltetrazolium]\}, which is yellow in color, to a product called formazana, which is blue or violet in color. Thus, the amount of formazan measured by spectrophotometry is directly proportional to the number of viable cells (PORTO et al. 2011).

By analyzing the cytotoxic activity of apitoxin it was reported that in concentrations of $50 \mu \mathrm{g} / \mathrm{mL}$ and $25 \mu \mathrm{g} / \mathrm{mL}$ there was a significant increase in cell viability in on non-neoplastic normal cells (L929) compared to the cell viability in human tumor cells of prostate adenocarcinoma (PC3), hepatocellular carcinoma (HEPGE2), astrocytoma (SNB19), and melanoma (MAD-MB435) strains.

Aptxin showed a selective effect for strains PC3, SNB19 and MAD-MB435. According to HORII et al. (2012), the selectivity index equal to 1 means that there is no selectivity between the strains studied, less than 1, means that the treatment is more selective for the fibroblast lineage (L929) than for the neoplastic strains and greater than 1 , means that there is selectivity for the tumor line studied. This result is quite expressive since doxorubicin (chemotherapy

Table 1 - Mean \pm standard deviation of DNA damage indices (idDNA), analyzed by comet assay for evaluation of the genotoxic effect of apitoxin after exposure of L929 fibroblasts for $24 \mathrm{~h}$ in three concentrations of the aqueous apitoxin solution to peroxide, hydrogen peroxide $\left(\mathrm{H}_{2} \mathrm{O}_{2}\right)$, or sterile distilled water.

\begin{tabular}{lcccccc}
\hline Parameter & - & & & & Control+ & Control - \\
\hline & 5 & 10 & 30 & 50 & & \\
IdDNA & $8.15 \pm 2.36^{c}$ & $8.66 \pm 2.50^{\mathrm{c}}$ & $12.33 \pm 2.87^{\mathrm{c}}$ & $29.11 \pm 3.88^{\mathrm{b}}$ & $176.33 \pm 21.00^{\mathrm{a}}$ & $7.88 \pm 2.66^{\mathrm{c}}$
\end{tabular}

${ }^{\mathrm{a}, \mathrm{b}, \mathrm{c}}$ Means followed by different lower case letters on the line means statistical difference $(P<0.05)$. Means on the same line followed by equal letters are statistically equal. IdDNA: DNA damage index; positive control $(+)$ : hydrogen peroxide (H2O2); negative control (-): Distilled water. 
Table 2 - Mean \pm standard deviation of the percentage reduction of genotoxicity induced by $\mathrm{H}_{2} \mathrm{O}_{2}$ in L929 fibroblasts co-treated with three concentrations of the aqueous apitoxin solution analyzed by the comet assay.

\begin{tabular}{lccc}
\hline Parameter & 5 & 10 & 30 \\
\hline$\%$ genotoxicity reduction & $7.29 \pm 6.67$ & $18.47 \pm 2.64$ & $51.20 \pm 10.60$ \\
\hline
\end{tabular}

used as a control) induced greater cytotoxicity in nonneoplastic cells (Table 4).

Our study demonstrated more satisfactory results than previous studies, where growth of hepatocellular carcinoma neoplastic cells was inhibited by bee venom with IC50 greater than $10 \mu \mathrm{g} / \mathrm{ml}$ (WANG et al., 2009). Moreover, it corroborated the study developed by PARK et al. (2011), who demonstrated that bee venom and melittin inhibited prostate cancer cell growth at similar or higher doses $(1-15 \mu \mathrm{g} / \mathrm{ml})$.

Despite the studies carried out and the investments made in research in the areas of chemistry and pharmacology of antineoplastic chemotherapy drugs, conventional chemotherapy drugs currently used in cancer treatment are highly toxic because they are poorly selective (CHEN et al., 2013). In this context, the main objective of chemotherapy studies is the search for new selective drugs capable of destroying only tumor cells and preserving normal cells (ANAZETTI et al., 2003). Thus, apitoxin's selective effect is an extremely important finding for possible use as a natural agent with antineoplastic activity.
Determining the IC50 value is an important step in cytotoxicity studies. As described, the cells were subjected to varying concentrations of the aqueous apitoxin solution to determine the concentration that caused significant death in $50 \%$ of the total cells tested. When analyzing the IC50 values reported here, values ranging from $3.97 \mu \mathrm{g} /$ $\mathrm{mL}$ to $9.85 \mu \mathrm{g} / \mathrm{mL}$ were found for HEPG2 to MADMB435 strains, respectively. The IC50 value was $9.45 \mu \mathrm{g} / \mathrm{mL}$ for non-neoplastic L929 cells (Table 4). Doxorubicin, used as a reference chemotherapy, also had IC50 values ranging from $0.10 \mu \mathrm{g} / \mathrm{mL}$ to 0.48 $\mu \mathrm{g} / \mathrm{mL}$ for PC3 to SNB19 strains, respectively. In analyzing these results, we considered IC50 values as satisfactory for all neoplastic strains tested.

The low IC50 values obtained can be translated as a higher sensitivity of these cells to apitoxin. Importantly, as an antitumor activity parameter, the United States National Cancer Institute (NCI) anticancer drug screening program considers compounds with antineoplastic activity as compounds with IC50<30 $\mu \mathrm{g} / \mathrm{mL}$ (ITHARAT et al.,

Table 3 - Cytotoxic effect of apitoxin produced by Apis mellifera bee in semiarid Rio Grande do Norte analyzed using the MTT technique on human tumor strains prostate adenocarcinoma (PC3), hepatocellular carcinoma (HEPGE2), astrocytoma (SNB19), melanoma (MAD-MB435), and non-neoplastic fibroblast cells (L929). Cells were treated with different concentrations of apitoxin solution for 72 hours. Results are expressed as mean percentage \pm standard deviation of cell viability.

\begin{tabular}{|c|c|c|c|c|c|}
\hline \multirow[t]{2}{*}{ Concentration $(\mu \mathrm{g} / \mathrm{ml})$} & \multicolumn{5}{|c|}{ 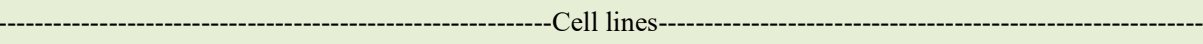 } \\
\hline & PC3 & HEPG2 & SNB19 & MAD-MB435 & L929 \\
\hline 50 & $0.40 \pm 0.28^{\mathrm{Db}}$ & $0.41 \pm 0.17^{\mathrm{Db}}$ & $0.44 \pm 0.25^{\mathrm{Cb}}$ & $0.41 \pm 0.25^{\mathrm{Cb}}$ & $53.23 \pm 1.98^{\mathrm{Ca}}$ \\
\hline 25 & $4.18 \pm 1.59^{\mathrm{Cc}}$ & $8.47 \pm 6.11^{\mathrm{Cd}}$ & $0.54 \pm 0.31^{\mathrm{Ce}}$ & $2.64 \pm 0.31^{\mathrm{Cc}}$ & $56.25 \pm 4.48^{\mathrm{CBa}}$ \\
\hline 12.5 & $45.6 \pm 5.55^{\mathrm{Ba}}$ & $39.14 \pm 3.8^{\mathrm{Ba}}$ & $39.35 \pm 7.6^{\mathrm{Ba}}$ & $39.35 \pm 7.60^{\mathrm{Ba}}$ & $87.00 \pm 5.41^{\mathrm{Ba}}$ \\
\hline 6.25 & $78.07 \pm 2.95^{\mathrm{Ab}}$ & $72.77 \pm 3.9^{\mathrm{Ab}}$ & $78.48 \pm 3.18^{\mathrm{Aa}}$ & $72.28 \pm 3.18^{\mathrm{Aa}}$ & $94.94 \pm 4.21^{\mathrm{Aa}}$ \\
\hline 3.125 & $76.52 \pm 1.08^{\mathrm{Ac}}$ & $74.52 \pm 8.15^{\mathrm{Aa}}$ & $79.63 \pm 2.48^{\mathrm{Ab}}$ & $75.22 \pm 2.48^{\mathrm{Ab}}$ & $95.52 \pm 3.11^{\mathrm{Aa}}$ \\
\hline 1.5625 & $88.99 \pm 4.96^{\mathrm{Ab}}$ & $78.09 \pm 5.89^{\mathrm{Aa}}$ & $76.24 \pm 2.94^{\mathrm{Ac}}$ & $79.32 \pm 2.94^{\mathrm{Ac}}$ & $90.56 \pm 4.17^{\mathrm{Aa}}$ \\
\hline 0.78125 & $87.65 \pm 6.49^{\mathrm{Aa}}$ & $82.76 \pm 11.57^{\mathrm{Aa}}$ & $75.72 \pm 7.15^{\mathrm{Aa}}$ & $81.55 \pm 7.15^{\mathrm{Aa}}$ & $94.23 \pm 2.60^{\mathrm{Aa}}$ \\
\hline
\end{tabular}

A, B, C Averages followed by different upper case letters in the column and ${ }^{\mathrm{a}, \mathrm{b}, \mathrm{c}}$ different lower case letters in the row mean statistical difference $(P<0.05$ - Tukey). 
Table 4 - Means and standard deviations obtained for the inhibitory concentration (IC50) and Tumor selectivity index (TSI) values of apitoxin produced by Apis mellifera bee in semiarid Rio Grande do Norte, against the human neoplastic strains prostate adenocarcinoma (PC3), hepatocellular carcinoma (HEPGE2), astrocytoma (SNB19), melanoma (MAD-MB435) and nonneoplastic fibroblast cells (L929).

\begin{tabular}{|c|c|c|c|c|}
\hline \multirow[t]{2}{*}{ Cell lines } & \multicolumn{2}{|c|}{ 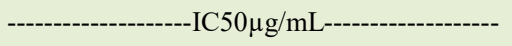 } & \multicolumn{2}{|c|}{ 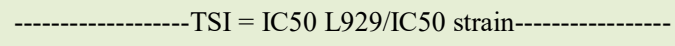 } \\
\hline & Apitoxin & Doxorubicin & Apitoxin & Doxorubicin \\
\hline $\mathrm{PC} 3$ & $7.75^{\mathrm{Aa}}$ & $0.10^{\mathrm{Bc}}$ & 1.22 & 2.00 \\
\hline HEPG2 & $9.85^{\mathrm{Aa}}$ & $0.20^{\mathrm{Bb}}$ & 0.96 & 1.00 \\
\hline SNB19 & $4.86^{\mathrm{Ab}}$ & $0.48^{\mathrm{Ba}}$ & 1.94 & 0.42 \\
\hline MAD-MB435 & $3.97^{\mathrm{Ab}}$ & $0.40^{\mathrm{Ba}}$ & 2.38 & 0.50 \\
\hline L929 & $9.45^{\text {Aa }}$ & $0.20^{\mathrm{Bb}}$ & 1.00 & 1.00 \\
\hline
\end{tabular}

A, B Averages followed by different upper case letters in the row and ${ }^{\mathrm{a}, \mathrm{b}}$ lower case different in the column means statistical difference $(P<0.05$ - Tukey).

2004). Also, according to the Institute, compounds with such IC50 values should undergo more detailed cytotoxicity analyses. It is also worth noting that there was a significant reduction between the IC50 values of the SNB19 and MAD-MB435 strains compared to the IC50 values obtained for L929 cells. These results confirmed that apitoxin shows selectivity over normal and neoplastic cell lines.

Other studies also showed satisfactory results regarding the antitumor potential of apitoxin. LIU et al. (2002) demonstrated that in vivo bee venom inhibited the proliferation of B16 melanoma cells and promoted the death of neoplastic cells by inducing apoptosis and DNA fragmentation. These factors are considered by the authors as possible mechanisms through which bee venom inhibits tumor growth. ORŠOLIĆ (2012) suggested that the fundamental mechanism of the cytotoxic effect of bee venom occurs through the activation of phospholipase A2 by melitin. MIRAN et al. (2012) reported that bee venom and its main component, melitin, inhibited human ovarian cancer epithelial cell growth (SKOV3 and PA-1) by inducing apoptosis in a dose concentrationdependent manner with an IC50 value of 1.5 and 3.8 $\mu \mathrm{g} / \mathrm{ml}$ in SKOV3 cells and 1.2 and $2.6 \mu \mathrm{g} / \mathrm{ml}$ in PA-1 cells, respectively.

\section{CONCLUSION}

The apitoxin produced by Apis mellifera bee in Northeast of Brazil showed good antioxidant activity. The comet assay indicated that apitoxin had no genotoxic effect except at $50 \mu \mathrm{g} / \mathrm{mL}$, and it promoted the antigenotoxic effect by reducing oxidative damage in 2929 cells. Apitoxin also demonstrated in vitro antineoplastic potential, since the cytotoxic effect was observed with significant reduction of viability percentages of human prostate adenocarcinoma (PC3) tumor cell lines, hepatocellular carcinoma (HEPGE2), melanoma (MAD-MB435), and astrocytoma (SNB19) at concentrations of 50 $\mu \mathrm{g} / \mathrm{mL}$ and $25 \mu \mathrm{g} / \mathrm{mL}$. In addition, apitoxin showed an antineoplastic selective action for PC3, MADMB435 and SNB19.

\section{ACKNOWLEDGEMENTS}

The authors thank beekeeper Joáz Ferreira da Silva for providing the apitoxin used in this study and was financed in part by the Coordenação de Aperfeiçoamento de Pessoal de Nível Superior (CAPES), Brasil - Finance code 001.

\section{DECLARATION OF CONFLICT OF INTERESTS}

The authors declare no conflict of interest. Sponsors had no role in the design of the study; in the collection, analysis or interpretation of data; in the writing of the manuscript and in the decision to publish the results.

\section{AUTHORS' CONTRIBUTIONS}

GAV and JSB conceived and designed experiments. CIAF, JGLA, GVDM, VHVR performed the experiments. JSB supervised and coordinated the experiments. WACC performed statistical analyses of experimental data. GAV, TST and JSB prepared the draft of the manuscript. All authors critically revised the manuscript and approved of the final version.

\section{REFERENCES}

ANAZETTI, M.C. et al. Comparative cytotoxicity of dimethylamide-crotonin in the promyelocytic leukemia 
cell line (HL60) and human peripheral blood mononuclear cells. Toxicology, v.188, n.2-3, p.261-274, 2003. Available from: $\quad<$ https://www.sciencedirect.com/science/article/abs/pii/ S0300483X03000891?via\%3Dihub>. Accessed: Mar. 29, 2019. doi: $10.1016 / \mathrm{s} 0300-483 \times(03) 00089-1$.

BAST, A. et al. Botanical health products, positioning and requirements for effective and safe use. Environmental Toxicology and Pharmacology, v.12, n.4, p.195-211, 2002. Available from: < https://www.sciencedirect.com/science/article/ pii/S1382668902000352>. Accessed: Jun. 28, 2019. doi: 10.1016/ S1382-6689(02)00035-2.

BASTOS, E. M. A. F. et al. Indicadores físico-químicos e atividade antibacteriana de própolis marrom frente à Escherichia coli. Arquivo Brasileiro de Medicina Veterinária e Zootecnia v.63, n.5, p.1255-1259, 2011. Available from: <https:// www.scielo.br/scielo.php?script $=$ sci_arttext\&pid $=$ S010209352011000500032\&lng=pt\&nrm $=$ iso $\&$ tlng $=p t>$. Accessed Apr. 14, 2019. doi: 10.1590/S0102-09352011000500032.

CAMPOS, R. P. et al. Conservação pós-colheita de guavira (Campomanesia sp.). Revista Brasileira de Fruticultura, v.34, n.1, p.41-49, 2012. Available from: <https://www.scielo.br/ scielo.php?pid=S0100-29452012000100008\&script $=$ sci_arttext $>$. Accessed: Jun. 12,2019. doi: 10.1590/S0100-29452012000400008.

CHEN, K.-C. et al. Selective cancer therapy by extracellular activation of a highly potent glycosidic duocarmycin analogue. Molecular pharmaceutics, v.10, n.5, p.1773-1782, 2013 Available from: <https://pubs.acs.org/doi/10.1021/mp300581u> Accessed: Aug. 05, 2019. doi: 10.1021/mp300581u.

CHUNG, Eun Sook et al. Neuro-protective effects of bee venom by suppression of neuroinflammatory responses in a mouse model of Parkinson's disease: role of regulatory T cells. Brain, behavior, and immunity, v.26, n.8, p.1322-1330, 2012. Available from: $\quad<$ https://www.sciencedirect.com/science/article/abs/pii/ S0889159112004217>. Accessed: Mar. 29, 2019. doi: 10.1016/j. bbi.2012.08.013

DE SOUZA, K. C. B. et al. LC determination of flavonoids: separation of quercetin, luteolin and 3-O-methylquercetin in Achyrocline satureioides preparations. Journal of pharmaceutical and biomedical analysis, v.28, n.3-4, p.771-777, 2002. Available from: <https://europepmc.org/article/med/12008157>. Accessed: Feb. 04, 2019. doi: 10.1016/s0731-7085(01)00693-8.

DOO, A-R. et al. Neuroprotective effects of bee venom pharmaceutical acupuncture in acute 1-methyl-4-phenyl-1, 2, 3, 6-tetrahydropyridine-induced mouse model of Parkinson's disease. Neurological research, v.32, n.sup1, p.88-91, 2010. Available from: <https://www.tandfonline.com/doi/abs/10.1179/0 16164109X12537002794282>. Accessed: Aug. 26, 2019. doi: 10 $.1179 / 016164109 \times 12537002794282$.

FERREIRA-JUNIOR, R. S. et al. Africanized honey bee (Apis mellifera) venom profiling: Seasonal variation of melittin and phospholipase A2 levels. Toxicon, v.56, n.3, p.355-362, 2010. Available from: < https://www.sciencedirect.com/science/article/ abs/pii/S004101011000142X?via\%3Dihub>. Accessed: May, 02, 2019. doi: 10.1016/j.toxicon.2010.03.023.

HAN, S. M. et al. Acute dermal toxicity study of bee venom (Apis mellifera L.) in rats. Toxicological research, v.28, n.2, p.99102, 2012. Available from: <https://www.ncbi.nlm.nih.gov/pmc/
articles/PMC3834407/>. Accessed: Nov. 16, 2019. doi: 10.5487/ TR.2012.28.2.099.

HORII, Haruka et al. Induction of non-apoptotic cell death in human oral squamous cell carcinoma cell lines by Rhinacanthus nasutus extract. In vivo, v.26, n.2, p.305-309, 2012. Available from: $<$ http://iv.iiarjournals.org/content/26/2/305.long >. Accessed: Jan. 21, 2020.

ITHARAT, A. et al. In vitro cytotoxic activity of Thai medicinal plants used traditionally to treat cancer. Journal of ethnopharmacology, v.90, n.1, p.33-38, 2004. Available from: $<$ https://www.sciencedirect. com/science/article/abs/pii/S0378874103003349?via\%3Dihub>. Accessed: Jul. 29, 2020. doi: 10.1016/j.jep.2003.09.014

KIM, H.-W. et al. Acupoint stimulation using bee venom attenuates formalin-induced pain behavior and spinal cord fos expression in rats. Journal of veterinary medical science, v.65, n.3, p.349355, 2003. Available from: <https://www.jstage.jst.go.jp/article/ jvms/65/3/65_3_349/_article>. Accessed: Oct. 22, 2019. doi: $10.1292 / \mathrm{jvms} .6 \overline{5} .349$.

KIM, J.-I. et al. Bee venom reduces neuroinflammation in the MPTP-induced model of Parkinson's disease. International Journal of Neuroscience, v.121, n.4, p.209-217, 2011a. Available from: <https://www.tandfonline.com/doi/abs/10.3109/00207454.2 010.548613? journalCode=ines20>. Accessed: Sep. 12, 2019. doi: $10.3109 / 00207454.2010 .548613$

KIM, S.-N. et al. Acupuncture enhances the synaptic dopamine availability to improve motor function in a mouse model of Parkinson's disease. PLoS One, v.6, n.11, 2011b. Available from: $<$ https://journals.plos.org/plosone/article/related?id=10.1371/ journal.pone.0027566>. Accessed: Feb. 04, 2019. doi: 10.1371/ journal.pone. 0027566 .

LEANDRO, L. F. et al. Antimicrobial activity of apitoxin, melittin and phospholipase A2 of honey bee (Apis mellifera) venom against oral pathogens. Anais da Academia Brasileira de Ciências, v.87, n.1, p.147-155, 2015. Available from: <https:// www.scielo.br/scielo.php? script $=$ sci arttext\&pid $=$ S0001$37652015000100147 \& \operatorname{lng}=$ en $\& n r m=$ iso $>$. Accessed: Mar. 25, 2020. doi: 10.1590/0001-3765201520130511.

LEE, S. M. et al. Effects of bee venom on glutamate-induced toxicity in neuronal and glial cells. Evidence-Based Complementary and Alternative Medicine, v.2012, 2012. Available from: <https:// www.hindawi.com/journals/ecam/2012/368196/>. Accessed: Jun. 23, 2018. doi: $10.1155 / 2012 / 368196$.

LIU, X. et al. Effect of honey bee venom on proliferation of K1735M2 mouse melanoma cells in vitro and growth of murine B16 melanomas in vivo. Journal of pharmacy and pharmacology, v.54, n.8, p.1083-1089, 2002. Available from: $<$ https://onlinelibrary.wiley.com/doi/abs/10.1211/00223570232 0266235 ? sid $=$ nlm\%3Apubmed $>$. Accessed: Mar. 05, 2019. doi: $10.1211 / 002235702320266235$.

MENSOR, L.L. et al. Screening of Brazilian plant extracts for antioxidant activity by the use of DPPH free radical method. Phytotherapy research, v.15, n.2, p.127-130, 2001. Available from: <https://onlinelibrary.wiley.com/doi/abs/10.1002/ptr.687>. Accessed: Dec. 29, 2018. doi: 10.1002/ptr.687.

NASCIMENTO, R. R. G. et al. Novos flavonoides de Margaritopsis carrascoana com atividade antioxidante. Química Nova, v.38, 
n.1, p.S1-S14, 2015. Available from: <https://www.scielo.br/pdf/ qn/v38n1/0100-4042-qn-38-01-0060.pdf>. Accessed: Jun. 26, 2019. doi: $10.5935 / 0100-4042.20140289$.

ORŠOLIĆ, N. Bee venom in cancer therapy. Cancer and Metastasis Reviews, v.31, n.1-2, p.173-194, 2012. Available from: $<$ https://link.springer.com/article/10.1007/s10555-011-9339-3>. Accessed: May, 04, 2019. doi: 10.1007/s10555-011-9339-3.

PARK, J. H., KIM, K. H., KIM, S. J., LEE, W. R., LEE, K. G., \& PARK, K. K. Bee venom protects hepatocytes from tumor necrosis factor- $\alpha$ and actinomycin D. Archives of Pharmacal Research, v.33, n.2, p.215-223, 2010. Available from: <https://link.springer. com/article/10.1007\%2Fs12272-010-0205-6>. Accessed: Oct. 27, 2018. doi: 10.1007/s12272-010-0205-6.

PARK, M. H. et al. Anti-cancer effect of bee venom in prostate cancer cells through activation of caspase pathway via inactivation of NF-кB. The Prostate, v.71, n.8, p.801-812, 2011. Available from: <https://onlinelibrary.wiley.com/resolve/doi?DOI=10.1002/ pros.21296>. Accessed: Sep. 15, 2018. doi: 10.1002/pros. 21296.

PORTO, I. C. et al. Cytotoxicity of current adhesive systems: in vitro testing on cell cultures of primary murine macrophages. Dental materials, v.27, n.3, p.221-228, 2011. Available from: $\quad<$ https://www.sciencedirect.com/science/article/abs/pii/ S010956411000446X?via\%3Dihub>. Accessed: Jul. 28, 2019. doi: 10.1016/j.dental.2010.10.006.

RATCLIFFE, N. A. et al. Insect natural products and processes: new treatments for human disease. Insect biochemistry and molecular biology, v.41, n.10, p.747-769, 2011. Available from: <https:// www.sciencedirect.com/science/article/pii/S0965174811001093>. Accessed: Aug. 06, 2019. doi: 10.1016/j.ibmb.2011.05.007.

SCIANI, J. M. et al. Identification of a novel melittin isoform from Africanized Apis mellifera venom. Peptides, v.31, n.8, p.14731479, 2010. Available from: <https:/www.sciencedirect.com/ science/article/abs/pii/S0196978110002056>. Accessed: Jul. 23 , 2019. doi: 10.1016/j.peptides.2010.05.001.
SOBRAL, F. et al. Chemical characterization, antioxidant, antiinflammatory and cytotoxic properties of bee venom collected in Northeast Portugal. Food and Chemical Toxicology, v.94, p.172177, 2016. Available from: <https://www.sciencedirect.com/ science/article/abs/pii/S0278691516301880>. Accessed: Sep. 09, 2019. doi: $10.1016 /$ j.fct.2016.06.008.

SUN, G. Y. et al. Phospholipase A2 in the central nervous system implications for neurodegenerative diseases. Journal of lipid research, v.45, n.2, p.205-213, 2004. Available from: <https:// www.jlr.org/content/45/2/205.long > . Accessed: Dec. 20, 2019. doi: 10.1194/j1r.R300016-JLR200

WANG, C. et al. Melittin, a major component of bee venom, sensitizes human hepatocellular carcinoma cells to tumor necrosis factor-related apoptosis-inducing ligand (TRAIL)-induced apoptosis by activating

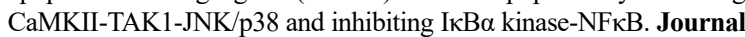
of Biological Chemistry, v.284, n.6, p.3804-3813, 2009. Available from: $<$ https://www.jbc.org/content/284/6/3804.long > . Accessed: Jan. 26, 2020. doi: 10.1074/jbc.M807191200.

YANG, E. J. et al. Melittin restores proteasome function in an animal model of ALS. Journal of neuroinflammation, v.8, n.1, p.69, 2011. Available from: <https://jneuroinflammation. biomedcentral.com/articles/10.1186/1742-2094-8-69>. Accessed: Nov. 23, 2019. doi: 10.1186/1742-2094-8-69.

YOON, M.-H. et al. Investigation of the neuroprotective effects of bee-venom acupuncture in a mouse model of Parkinson's disease by using immunohistochemistry and In-vivo $1 \mathrm{H}$ magnetic resonance spectroscopy at 9.4 T. Journal of the Korean Physical Society, v.62, n.2, p.320-327, 2013. Available from: <https://link.springer.com/ article/10.3938/jkps.62.320>. Accessed: Nov. 23, 2019.

ZHOU, J. et al. Quantification of melittin and apamin in bee venom lyophilized powder from Apis mellifera by liquid chromatographydiode array detector-tandem mass spectrometry. Analytical biochemistry, v.404, n.2, p.171-178, 2010. Available from: <https:// www.sciencedirect.com/science/article/abs/pii/S0003269710003337>. Accessed: Nov. 23, 2019. doi: 10.1016/j.ab.2010.05.014. 